\title{
Haemato-Biochemical Changes associated with Intramuscular Administration of Amikacin
}

\author{
Namrata Upadhyay ${ }^{1}$, Nitesh Kumar ${ }^{1}$, Arpita Shrivastav ${ }^{1}$, Swatantra Singh ${ }^{1}$, Neeraj \\ Shrivastava $^{2}$, Manoj Kumar Ahirwar ${ }^{3}$, Sumat Kumar Shakya ${ }^{4}$ and Rajeev Ranjan ${ }^{1 *}$ \\ ${ }^{1}$ Department of Veterinary Pharmacology and Toxicology, \\ ${ }^{2}$ Department of Veterinary Microbiology, \\ ${ }^{3}$ Department of Veterinary Physiology and Biochemistry, \\ ${ }^{4}$ Department Livestock Production and Management, College of Veterinary Science and A.H., \\ Rewa, (NDVSU, Jabalpur), Madhya Pradesh, India \\ *Corresponding author
}

\section{A B S T R A C T}

\section{Keywords}

Amikacin, Goats, Intramuscular,Haem ato-biochemical, Dosage

\section{Article Info}

\section{Accepted:}

12 April 2021

Available Online:

10 May 2021
Aminoglycosides are antibiotics, often used in veterinary and human medicine for treatment of various infections caused by gram negative and some gram positive micro-organisms. Due to its inherent property of being refractory to most aminoglycoside modifying enzymes. Amikacin has been successfully used to treat the life threatening antimicrobial resistant infections. These antibiotics is their relatively low therapeutic index. The use at therapeutic doses may lead to adverse changes in haemato-biochemical parameters, especially with those connected with kidney and liver function. The aim of the present study was to determine the changes in some haemato-biochemical parameters on $1^{\text {st }}, 3^{\text {rd }}, 5^{\text {th }}$ and $7^{\text {th }}$ days after intramuscular administration with amikacin at therapeutic dose @ $10 \mathrm{mg} / \mathrm{kg}$ bwt for 5 days in four healthy non lactating female goats. The results of present studies indicated that in healthy goats, at therapeutic doses of amikacin caused significant $(p<0.05)$ rise in serum BUN and creatinine level, but no significant $(\mathrm{p}<0.05)$ changed observed in blood Hb, PCV, TLC, lymphocytes, monocytes, eosinophils, basophil and neutrophils and the serum albumin, globulin, total protein, bilirubin, cholesterol and triglyceride level during the experiment. Amikacin also caused significant $(\mathrm{p}<0.05)$ rise in serum enzyme ALT, AST and ALP level. On the whole, the results of these studies demonstrate that amikacin have potential for altering biochemical and haematological values in female goats after using amikacin at therapeutic doses.

\section{Introduction}

The amikacin is most widely used semisynthetic aminoglycoside and it is derivative of aminoglycoside kanamycin-A., with improved efficacy and refractory to most aminoglycosides inactivating enzyme (Ries et al., 1973; Gerding et al., 1991). Its 
antimicrobial activity is primarily against aerobic gram-negative organisms of veterinary importance and limited activity against grampositive bacteria (Leitzke et al., 1998). They are also active against Staphylococci and certain Mycobacteria (Xiong et al., 1999). Amikacin is mainly administered intravenously, intramuscularly and other routes (Malinin et al., 2016; Tsimogianni et al., 2017). Amikacin with extended spectrum of activity have excellent therapeutic potential, but their applicability is limited by their nephrotoxic, ototoxic and neuroparalytic effects (Jenkins et al., 2016). Amikacin belong to the group of aminoglycosides with extended spectrum of antimicrobial activity (Pacifici and Marchini, 2017). They are insufficiently studied in veterinary medicine. The characteristic feature of these antibiotics is their relatively low therapeutic index. The use of therapeutic doses may lead to adverse changes in haemato-biochemical parameters, especially with those connected with liver and kidney function. The veterinarian therefore has to create a proper balance between their use as an antibiotic and these adverse effects to avoid any occasion of iatrogenicity. In veterinary medicine such data exist mainly for gentamicin and other aminoglycosides because of its wide application and its considerable nephrotoxic potential (Ramsay and Vulliet, 1993). Such information, considering amikacin is rather scarce for goats. Collection of such experimental data will prove to be useful for rational use of these antibiotics.

\section{Materials and Methods}

\section{Experimental animals}

The experiment was performed in four clinically healthy female non lactating goats of Sirohi breed between 1 to 2 years of age and 15 to $25 \mathrm{~kg}$ body weight. The experimental animals were maintained in the College of
Veterinary Science and Animal Husbandry, Rewa (M.P.) under uniform managemental conditions. The animals were dewormed before the commencement of the experimental study. During this entire period of experiment, animals were subjected to regular clinical examination, and maintained on dry as well as green fodder, concentrate and a routine grazing for at least 4 to 5 hours every day. Clean potable drinking water was provided $a d$ libitum. All the animals were apparently healthy during the study. The experimental protocol for general procedure and use of animals for conducting the present study has been reviewed and approved by the Institutional Animal Ethics Committee (IAEC), College of Veterinary Science \& AH, Rewa, Madhya Pradesh, India,

\section{Drugs}

The injectable commercial preparation containing amikacin equivalent to $250 \mathrm{mg} / \mathrm{ml}$ (Amidac, India) was used in present investigation. Amikacin was administered at the dose rate of $10 \mathrm{mg} / \mathrm{kg}$ bwt intramuscular in each of four healthy goats once daily at intervals of 24 hours for five consecutive days (Saini and Srivastava, 1998).

\section{Blood sampling and processing}

Blood samples for evaluation of haematobiochemical parameters were collected on the $1^{\text {st }}, 3^{\text {rd }}, 5^{\text {th }}$ and $7^{\text {th }}$ days $\left(2^{\text {nd }}\right.$ day of the last dose). Blood samples were collected into two tubes. The first tube contained anticoagulant (Na2 EDTA) for complete blood count (CBC) analysis. Blood samples in the other tube were left for a short of time to allow clotting. Serum samples were collected after centrifugation at $3000 \mathrm{rpm}$ for $20 \mathrm{~min}$. A clear serum samples were kept in a deep freeze for biochemical analysis. However determination of enzymes activity were carried out on fresh serum samples. 


\section{Haematological Parameters}

The whole blood was used for the estimation of haemoglobin $(\mathrm{Hb})$, packed cell volume (PCV), total erythrocyte count/red blood cell count (TEC/RBC) and total leucocyte count/white blood cell count (TLC/WBC). The haematological parameter was carried out as per the procedure mentioned by Jain (1986).

\section{Biochemical Parameters}

Serum was separated from the blood without anticoagulant from the experimental animals. The serum was used for the estimation of BUN, creatinine, bilirubin, albumin, total protein, cholesterol, triglycerides, aspartate aminotransferase (AST), alanine amino transferase (ALT), alkaline phosphatase (ALP) either on the day of collection or stored for subsequent analysis. Serum biochemical parameters was determined using Erba EM200 Automated Biochemistry Analyzer. Transasia (ERBA) Biochemistry Test Kits were used for the analysis as per the manufacturer's instruction.

\section{Statistical analysis}

Data are presented in Means \pm Standard Error (SE). The data was analyzed using statistical tools (SPSS version 16). ANOVA followed by Multiple Range, Duncan's Test was used for multiple comparisons. Statistical differences were determined at the $5 \%$ level of significance.

\section{Results and Discussion}

Various haemato-biochemical parameters were performed for evaluation of the functions of the different organ. Amikacin is very common aminoglycosides used as a therapeutic agent against infections. But longterm exposure of aminoglycosides antibiotics may induce hepato-renal toxicity (Stojiljkovic and Stoiljkovic, 2006; Masakazu et al., 2014). The food consumption, water intake, general behavior and body weight of the goat did not show any apparent change during the amikacin administration. Studies on haematological parameters can easily reveal abnormalities in body metabolic processes, and the blood profile usually provides important information on the response of the body to lesion or injury, stress and deprivation (Bosco et al., 2014). Therefore, the extent of toxic effect of drugs and/or chemical can be determined by assessment of haematological parameters (Raza et al., 2002).

In the present study, the concentration of $\mathrm{Hb}$, PCV, TEC, TLC, lymphocyte, monocyte, eosinophil, basophil and neutrophil count did not show any significant $(\mathrm{p}<0.05)$ changes during intramuscular administration of amikacin on $1^{\text {st }} \cdot 3^{\text {rd }}, 5^{\text {th }}$ and $7^{\text {th }}$ day (Table 1). The present results are in accordance to that of Baidya et al., (1994), who observed that administration of antibiotics do not have any influence on the hemoglobin concentration and differential leukocyte count (DLC). Similarly, Elyazji et al., (2013) assessed that there is an insignificant decrease in TEC after gentamicin administration. Our findings are in contrary to the results of Dinev et al., (2005) who reported that there is tendency toward a decrease of TEC, haemoglobin concentration and haematocrit percentage after 5 days intramuscular administration with amikacin $(10 \mathrm{mg} / \mathrm{kg}$ bwt $)$ in healthy female goats. Contrary result also observed by Jannat et al., (2018), who reported significantly reduced the TEC, TLC and $\mathrm{Hb}$ after gentamicin administration. Another findings were reported by Lijana and Williams (1986) after a long term exposure of aminoglycosides in high dose affects the haemopoietic cells in the bone marrow and decrease erythrocyte production. The present result are also contradictory to the El Badwi, (2012) 
according to whom, in gentamicin treated rats the values of PCV were significantly reduced. It also goes similar with the findings of Nale et al.,(2013) who explained in his experiment that there was significant reduction in PCV after gentamicin administration in rats. However, Izat et al., (1998) who reported that PCV value of blood in mice is enhanced by gentamicin administration.

In the present study, there is no significant ( $\mathrm{p}$ $<0.05$ ) change in serum albumin, globulin, total protein, biluribin, cholesterol and triglyceride concentration on the $1^{\text {st }}, 3^{\text {rd }}, 5^{\text {th }}$ and $7^{\text {th }}$ day (Table 2). These finding are in close agreement with Anitha et al., (2016) who reported that cholesterol, total triglycerides, bilirubin, total protein and albumin did not show any significant change after amikacin administration. Abu-Spetan et al., (2001) also reported that gentamicin treatment produces significant elevation in the cholesterol level. Balasinka and Mazur (2004) and Akter et al., (2013) who also stated that mice treated with gentamicin showed a significant increase in blood cholesterol and triglyceride level.

Elevated serum enzymes levels produced by the liver and nitrogenous wastes to be excreted by the kidney might be indications to their spillage into the blood stream as a result of necrosis of the tissues (Mikhael et al., 2010).

The liver is a primary destination for any toxic substance entered to the body, especially through gastrointestinal route, the liver will affected first. Because of its wide range of functions, any abnormal change in hepatocytes will definitely affect complete metabolism of an animal (Paliwal et al., 2009). Because, liver is important organ to encounter ingested nutrients, vitamins, metals, drugs, and environmental toxicants (Curtis, 2007). There are several serum chemistries that reflect liver function. The most commonly used serum liver chemistry tests include serum transaminases (eg-ALT and AST), serum alkaline phosphatase (ALP), bilirubin, albumin etc. The major intracellular enzymes of the liver are ALT and AST. However, injuries of hepatocytes allowing for escape of these enzymes into the bloodstream raises their levels in the blood (Thapa and Walia, 2007). The levels of ALP in the serum are important parameters for evaluation of hepatobiliary route (Raza et al., 2002). AST is not specific for liver because AST is also present in red blood cells, cardiac muscle, skeletal muscle, kidney and brain tissue, and may be elevated due to damage to these sources as well. AST is also known as a biochemical marker for the diagnosis of acute myocardial infarction (Gaze, 2007). Unlike AST, ALT is fairly specific being found largely in the liver and it is commonly used as a biomarker for liver problems (Giboney, 2005). Elevation of serum levels of both AST and ALT may occur with states of altered hepatocellular membrane permeability.

Kidney is a very sensitive organ, whose function is known to be regulated by a number of factors such as different drugs/ phytochemical/pollutants that ultimately lead to renal failure. Kidney function test is a collective term for a variety of individual tests and procedures that can be done to evaluate how well the kidneys are functioning (Abdelkader et al., 2012). Accordingly, renal function can be assessed by measuring the levels of plasma creatinine and urea concentrations (Abdel-kader et al., 2012). Assessment of possible renal damage due to drug in this study was made by assaying plasma urea and creatinine levels (Stark, 1980). 
Table.1 Comparative haematological values after intramuscular administration of amikacin in the healthy goats

\begin{tabular}{|c|c|c|c|c|}
\hline Parameter & $\mathbf{1}^{\text {st }}$ Day & $\mathbf{3}^{\text {rd }}$ Day & $\mathbf{5}^{\text {th }}$ Day & $\mathbf{7}^{\text {th }}$ day \\
\hline $\mathrm{Hb}\left(\mathrm{g} . \mathrm{dl}^{-1}\right)$ & $10.32 \pm 0.10$ & $10.37 \pm 0.10$ & $10.43 \pm 0.09$ & $10.46 \pm 0.06$ \\
\hline $\mathrm{PCV}(\%)$ & $30.75 \pm 1.10$ & $31.25 \pm 0.25$ & $32.00 \pm 0.40$ & $31.50 \pm 0.28$ \\
\hline TEC $\left(10^{\mathbf{6}} \cdot \mu \mathrm{l}^{-1}\right)$ & $11.75 \pm 0.95$ & $11.50 \pm 0.90$ & $11.25 \pm 0.85$ & $11.35 \pm 0.85$ \\
\hline TLC $\left(10^{3} \cdot \mu 1^{-1}\right)$ & $8.83 \pm 0.70$ & $8.88 \pm 0.76$ & $9.36 \pm 0.39$ & $8.93 \pm 0.25$ \\
\hline Lymphocytes (\%) & $55.25 \pm 1.88$ & $54.00 \pm 1.58$ & $56.25 \pm 1.25$ & $55.75 \pm 1.65$ \\
\hline Monocytes (\%) & $0.75 \pm 0.25$ & $1.00 \pm 0.40$ & $1.25 \pm 0.25$ & $1.25 \pm 0.25$ \\
\hline Eosinophils (\%) & $1.00 \pm 0.40$ & $1.00 \pm 0.40$ & $1.25 \pm 0.25$ & $1.00 \pm 0.00$ \\
\hline Basophils (\%) & $0.50 \pm 0.28$ & $0.75 \pm 0.25$ & $0.50 \pm 0.28$ & $0.50 \pm 0.28$ \\
\hline Neutrophils (\%) & $39.50 \pm 0.64$ & $40.50 \pm 0.50$ & $40.50 \pm 0.50$ & $41.25 \pm 0.47$ \\
\hline
\end{tabular}

Values are expressed as mean $\pm \mathrm{SE}$ of four animals in each group.

Table. 2 Comparative serum biochemical values after intramuscular administration of amikacin in the healthy goats

\begin{tabular}{|c|c|c|c|c|}
\hline Parameter & $1^{\text {st }}$ Day & $3^{\text {rd }}$ Day & $5^{\text {th }}$ Day & $7^{\text {th }}$ day \\
\hline Albumin $\left(\mathrm{g} \cdot \mathrm{dl}^{-1}\right)$ & $3.01 \pm 0.21$ & $2.95 \pm 0.22$ & $2.97 \pm 0.22$ & $2.88 \pm 0.23$ \\
\hline Globulin (g.dl $\left.{ }^{-1}\right)$ & $4.02 \pm 0.25$ & $3.85 \pm 0.17$ & $3.92 \pm 0.19$ & $3.79 \pm 0.16$ \\
\hline Total Protein $\left(\mathrm{mg} \cdot \mathrm{dl}^{-1}\right)$ & $6.69 \pm 0.06$ & $6.73 \pm 0.06$ & $6.69 \pm 0.06$ & $6.76 \pm 0.06$ \\
\hline $\mathrm{BUN}\left(\mathrm{g} \cdot \mathrm{dl}^{-1}\right)$ & $19.00 \pm 0.41^{\mathrm{a}}$ & $20.25 \pm 0.63^{\mathrm{ab}}$ & $21.75 \pm 0.49^{b}$ & $22.25 \pm 0.48^{b}$ \\
\hline Creatinine $\left(\mathrm{mg} \cdot \mathrm{dl}^{-1}\right)$ & $1.23 \pm 0.012^{\mathrm{a}}$ & $1.24 \pm 0.01^{\mathrm{a}}$ & $1.28 \pm 0.0041^{\mathrm{b}}$ & $1.27 \pm 0.006^{b}$ \\
\hline Total bilirubin $\left(\mathrm{mg} \cdot \mathrm{dl}^{-1}\right)$ & $0.46 \pm 0.004$ & $0.46 \pm 0.008$ & $0.47 \pm 0.008$ & $0.47 \pm 0.011$ \\
\hline Cholesterol (mg.dl $\left.{ }^{-1}\right)$ & $49.75 \pm 1.65$ & $50.25 \pm 2.32$ & $50.50 \pm 2.53$ & $50.40 \pm 2.65$ \\
\hline Triglyceride $\left(\mathrm{mg} \mathrm{dl}^{-1}\right)$ & $38.75 \pm 1.93$ & $40.00 \pm 1.68$ & $40.00 \pm 1.22$ & $42.75 \pm 1.30$ \\
\hline ALT/GPT (IU.L-1) & $25.00 \pm 1.47^{\mathrm{a}}$ & $25.25 \pm 1.03^{\mathrm{a}}$ & $33.25 \pm 1.31^{\mathrm{b}}$ & $32.00 \pm 1.58^{b}$ \\
\hline AST/GOT (IU.L $\left.{ }^{-1}\right)$ & $66.25 \pm 4.38^{\mathrm{a}}$ & $69.00 \pm 4.38^{\mathrm{ab}}$ & $77.25 \pm 1.10^{b}$ & $77.00 \pm 1.87^{\mathrm{b}}$ \\
\hline ALP $\left(\right.$ IU.L $\left.L^{-1}\right)$ & $168.50 \pm 5.38^{\mathrm{a}}$ & $172.50 \pm 4.78^{\mathrm{ab}}$ & $189.25 \pm 5.85^{b}$ & $179.75 \pm 4.28^{\mathrm{ab}}$ \\
\hline
\end{tabular}

Values are expressed as mean \pm SE of four animals in each group.

Values bearing different superscript in small letter differ significantly in row respectively $(p<0.05)$.

In the present study, the mean plasma creatinine, BUN, AST, ALT and ALP concentration $(\mathrm{p}<0.05)$ was significantly increased after intramuscular administration of amikacin at therapeutic dosage in healthy goats (Table 2). These results are in close agreement with other reported cases for amikacin (Dinev et al., 2005), tobramycin (Jernigan et al., 1988) and gentamicin (Ramsay and Vulliet, 1993; Lashev and Lasarova, 2001) treatment at therapeutic doses. El Badwi (2012) who stated that the gentamicin treated group scored the higher values of urea. Similarity Elyazji et al., (2013) and Shahidullah et al., (2016) who stated that a significant increase in serum creatinine when administration of gentamicin for longer time duration. However, AST, ALT and ALP enzymes increased with liver damage (Harr, 2002). Liver enzymes indicated the alteration in cell membrane integrity or biliary epithelium (Eran et al., 2007). Many previous reports showed the decrease in total protein and albumin levels and increase in ALT and 
creatinine levels with gentamicin administration (Saleemi et al., 2009).

The possibility that therapeutic dosage of some drugs may cause minor changes in some of the haemato-biochemical parameters. It may show that oxidative stress responsible for increased production of reactive oxygen species associated with an increase in lipid peroxidation, which takes place in the cell membranes or tissue and ultimately leading to cellular damage. Therefore it could be constitute as minor treatment hazards. Because, liver is the first organ to encounter ingested nutrients, vitamins, metaltitute minor treatment hazards. These results might be accepted as a starting point for future experiments in a direction aimed at inculcating safety measures in aminoglycoside antibiotics use.

\section{Acknowledgment}

Authors are thankful to College of Veterinary Science \& A. H., Rewa (NDVSU, Jabalpur), Madhya Pradesh for providing the necessary facilities to conduct the research.

\section{References}

Abdel-kader, M. A. and Mohamod, N. Z. 2012. Evaluation of protective and antioxidant activity of thyme (Thymus vulgaris) extract on paracetamol induced toxicity in rats. Aust. J. Basic Appl. Sci., 6:467474.

Abu-Spetan, K., Abdel-Gayoum and Bashir, A. A. 2001. Effect of high dietary cholesterol on gentamicin-induced nephrotoxicity in rabbits. Arch. Toxicol., 75(5):284-290.

Akter, S., Miah, M. A., Khan, M. and Islam, M.K. 2013. Effects of gentamicin on high fat induced hypercholesterolemic mice. Br. Biotechnol. J., 3:39-53.

Anitha, R., Vijayaraghavan, R., Geetha, R. V., Anitha, M., Vishnu Priya, S., Anusha,
R., Vidyalakshimi, U., Raaga, N. K., Mohan, S.K. and Chakkaravarthy, M. (2016). A comparative study of the effect of amikacin administered through autoinjector and manual injection on biochemical parameters in rats. J. App. Pharm. Sci., 6(02): 109-114.

Baidya, N., Mandal, L., Sarkar, S. K. and Banerjee, G. C. 1994. Combined feeding of antibiotic and probiotic on the performance of broiler. Ind. J. Poult. Sci., 29(3):228-231.

Bałasinska, B. and Mazur, A. 2004. Oxidized dietary lipids may participate in the development of atherosclerosis. PostepyHig. Med. Dosw., 58:176-182.

Bosco, A. D., Gerencser, Z., Szendro, Z., Ugnai, C., Cullere, M., Kovacs, M., Ruggeri, S., Mattioli, S., Castellini, C. and Zotte D.A. 2014. Dietary supplementation of spirulina (Arthrospira platensis) and Thyme (Thymus vulgaris) on rabbit meat appearance, oxidative stability and fatty acid profile during retail display. Meat Sci., 96:114-119.

Curtis, D. K. 2007. Casarett and Doull's Toxicology: The basic science of poisons, $7^{\text {th }}$ edition, The McGraw-Hill Companies.

Dinev, T., Kanakov, D. and Zapryanova D. 2005. Investigations on some biochemical and haematological parameters after tobramycin and amikacin treatment in female goats. Trakia J. Sci. 3(5): 14-16.

El Badwi, S. M. A., Bakhiet, A. O. and Abdel Gadir, E. H. 2012. Heamato-biochemical effect of aqueous extract of Khaya senegalensis stem bark on gentamicininduced nephrotoxicity in wistar rats. J. Biol. Sci., 12(6):361-366.

Elyazji, N. R., Islam, M. N. and Abdel-Aziz, I. 2013. Some haematological and physiological changes associated with gentamicin and/or novalgin injection in rabbits. Int. J. Pharm. Chem. Biol. Sci., 3(1):172-181.

Eran, E., Galia, P., Rifaat, S. and Orit, P. 2007. Association between consumption of 
Herbalife ${ }^{\circledR}$ nutritional supplements and acute hepatotoxicity. J. Hepatol., 47:514-520.

Gaze, D. C. 2007. The role of existing and novel cardiac biomarkers for cardioprotection. Curr. Opin. Investig. Drugs, 8: 711-717.

Gerding, D. N., Larson, T. A., Hughes, R. A., Weiler, M., Shanholtzer, C., Peterson, L.R. 1991. Aminoglycoside resistance and aminoglycoside usage: Ten years of experience in one hospital. Antimicrob. Agents Chemother., 35:1284-1290.

Giboney, P. T. 2005. Mildly elevated liver transaminase levels in the asymptomatic patient. Am. Fam. Physician, 71:11051110.

Harr, K. E. 2002. Clinical chemistry of companion avian species: a review. Vet. Clin. Pathol. 31: 140-151.

Izat, I., Gerber, A. U., Craig, W. A., Brugger, H. P., Feller, C., Vastola, A. P. and Brandel, J. 1983. Impact of dosing intervals on activity of gentamicin and ticarcillin against Pseudomonas aeruginosa in granulocytopenic mice. J. Infect. Dis., 147(5):910-917.

Jain, N. C. (1986). Schalm's Veterinary Haematology $4^{\text {th }}$ edition. Lea and Febiger, Philadelphia.

Jannat, N., Amin, T., Sultana, N., Jahan, M. R. and Islam, M.R. 2018. Long term administration of gentamicin affects haemato-biochemical parameters and liver architecture of Swiss Albino mice. J. Adv. Biotechnol. Exp. Ther., 1(2):2935.

Jenkins, A., Thomson, A. H., Brown, N. M., Semple, Y., Sluman, C., MacGowan, A., Lovering, A. M., Wiffen, P. J. 2016. Amikacin use and therapeutic drug monitoring in adults: Do dose regimens and drug exposures affect either outcome or adverse events? A systematic review. J. Antimicrob. Chemother., 71:2754-2759.

Jernigan, A. D., Hatch, R. C. and Wilson, R. C. 1988. Pharmacokinetics of tobramycin in cats. Am. J. Vet. Res., 49:608-612.

Jernigan, A. D., Hatch, R. C., Willson, R. C.,
Brown, J. and Crowell, W. A. 1988. Pathologic changes and tissue gentamicin concentration after intravenous gentamicin administration in clinically normal and endotoxemic cats. Am. J. Vet. Res., 49:613-617.

Lashev, L. and Lasarova, S., 2001. Pharmacokinetics and side effects of gentamicin in healthy and Pseudomonas aeruginosa infected sheep. J. Vet. Pharm. Ther., 24:237-240.

Leitzke, S., Bucke, W., Borner, K., Muller, R., Hahn, H., Ehlers, S. 1998. Rationale for and efficacy of prolonged-interval treatment using liposome-encapsulated amikacin in experimental Mycobacterium avium infection. Antimicrob. Agents Chemother., 42:459-461.

Lijana, R. C. and Williams, M. C. 1986. The effects of antibiotics on hemolytic behavior of red blood cell. Cell Biophys., 8(4): 223-242.

Malinin, V., Neville, M., Eagle, G., Gupta, R. and Perkins, W. R. 2016. Pulmonary deposition and elimination of liposomal amikacin for inhalation and effect on macrophage function after administration in rats. Antimicrob. Agents Chemother., 60:6540-6549.

Masakazu, K., Yoshiko, E., Masashi, E. 2014. Acquired resistance of Listeria monocytogenes in and escaped from liver parenchymal cells to gentamicin is caused by being coated with their plasma membrane. Microbes Infect., 16(3):237-243.

Mikhael, M., Orr, R., Amsen, F., Greene, D., Singh, M.A. 2010. Effect of standing posture during whole body vibration training on muscle morphology and function in older adults: a randomized controlled trial. BMC Geriatr., 10:74.

Nale, L. P., More, P. R., More, B. K., Ghumare, B. C., Shendre, S. B. and Mote, C. S. 2012. Protective effect of Carica papaya seed extract in gentamicin induced hepatotoxicity and nephrotoxicity in rats. Int. J. Pharma Bio. Sci., 3(3):508-515. 
Pacifici, G. and Marchini, G. 2017. Clinical pharmacokinetics of amikacin in neonates. Int. J. Pediatr., 5:4407-4428.

Paliwal, A., Gurjar, R. K. and Sharma, H. N. 2009. Analysis of liver enzymes in albino rat under stress of $\lambda$-cyhalothrin and nuvan toxicity. Biol. and Medic.,2:70-73.

Ramsay, E. C. and Vulliet, R. 1993. Pharmacokinetic properties of gentamicin and amikacin in the Cockatiel. Avian dis.,37:628-634.

Raza, M., Al-Shabanah, O. A., El-Hadiyah, T. M. and Al-Majed, A. A. 2002. Effect of prolonged vigabatrin treatment on haematological and biochemical parameters in plasma, liver and kidney of Swiss albino mice. Pharmace. Scien., 70:135-145.

Ries, K., Levison, M. E. and Kaye, D. 1973. In vitro evaluation of a new aminoglycoside derivative of kanamycin, BBKA: a comparison with tobramycin and gentamycin. Antimicrob. Agents Chemother., 3:532533.

Saini, S. P. and Srivastava, A. K. 1998. The disposition kinetics, urinary excretion and dosage regimen of amikacin in cross bred bovine calves. Vet. Res. Commun., 22:59-65.

Saleemi, M. K., Khan, M. Z., Khan, A. and Javed, I. 2009. Pathological effects of gentamicin administered intramuscularly today old broiler chicks. Exp. Toxicol. Path., 61:425-432.
Shahidullah, A. F. M., Bhuiyan, M. E. R., Hossain, M. I., Islam, M. R., Riaz, M.M.U. 2016. Effects of gentamicin on growth performance and haematobiochemical parameters in mice. Int. J. Nat. Soc. Sci. 3(4):43-51.

Stark, J. L. 1980. BUN/creatinine: your keys to kidney function. Nursing 10:33-38.

Stojiljkovic, N. and Stoiljkovic, M. 2006. Micromorphological characteristics of the liver and biochemical analyses in the blood of rats treated by gentamicin and verapamil. Acta Med. Medianae, 45(2):5-9.

Thapa, B. R. and Walia, A. 2007. Liver function test and their interpretation. Indian $\mathrm{J}$. Pediatr., 74:663-671.

Tsimogianni, A., Alexandropoulos, P., Chantziara, V., Vassi, A., Micha, G., Lagiou, F., Chinou, E., Michaloudis, G. and Georgiou, S. 2017. Intrathecal or intraventricular administration of colistin, vancomycin and amikacin for central nervous system infections in neurosurgical patients in an intensive care unit. Int. J. Antimicrob. Agents., 49:389-390.

Xiong, Y. Q., Caillon, J., Kergueris, M. F., Drugeon, H., Baron, D., Potel, G., Bayer, A.S. 1997. Adaptive resistance of Pseudomonas aeruginosa induced by aminoglycosides and killing kinetics in a rabbit endocarditis model. Antimicrob. Agents Chemother., 41(4): 823-826.

\section{How to cite this article:}

Namrata Upadhyay, Nitesh Kumar, Arpita Shrivastav, Swatantra Singh, Neeraj Shrivastava Manoj Kumar Ahirwar, Sumat Kumar Shakya and Rajeev Ranjan. 2021. Haemato-Biochemical Changes associated with Intramuscular Administration of Amikacin. Int.J.Curr.Microbiol.App.Sci. 10(05): 195-202. doi: https://doi.org/10.20546/ijcmas.2021.1005.026 